\title{
Gallium Ga 68-NeoB
}

National Cancer Institute

\section{Source}

National Cancer Institute. Gallium Ga 68-NeoB. NCI Thesaurus. Code C154381.

A radioconjug ate consisting of the gastrin-releasing peptide receptor (GRPR) antagonist, NeoBOMB1, linked via the chelating agent, dodecanetetraacetic acid (DOTA), to the beta-emitting radioisotope gallium $\mathrm{Ga} 68$, with potential imaging activity during positron emission topography/computed tomography (PET/CT). Upon administration, gallium Ga 68-DOTA-NeoBOMB1 binds to GRPRs present on cancer cells. Upon binding, this radioconjugate can be used to quantify tumor uptake of NeoBOMB1 using PET/CT. GRPR, also known as bombesin receptor subtype 2, is a G-protein-coupled receptor that is overexpressed in some cancer types. 